\section{Associations between self-perceived quality of life and socio-demographic, psychosocial, and health variables in a group of elderly}

\author{
Relações entre qualidade de vida percebida e \\ variáveis sociodemográficas, psicossociais e \\ de saúde em idosos
}

\author{
Relaciones entre calidad de vida percibida y \\ variables sociodemográficas, psicosociales y \\ de salud en ancianos
}

Sérgio Eduardo Silva de Oliveira 1 Jean Von Hohendorff 1 Juliana de Lima Müller 1 Denise Ruschel Bandeira 1 Sílvia Helena Koller 1 Marcelo Pio de Almeida Fleck 1 Clarissa Marceli Trentini 1

\author{
1 Universidade Federal do Rio \\ Grande do Sul, Porto Alegre, \\ Brasil. \\ Correspondece \\ S. E. S. Oliveira \\ Universidade Federal do \\ Rio Grande do Sul. \\ Rua Ramiro Barcelos 2600 \\ Porto Alegre, RS 90035-003, \\ Brasil. \\ sergioeduardos.oliveira@ \\ gmail.com
}

\begin{abstract}
The objectives of this study were to investigate: (a) multiple relations between socio-demographic, psychosocial, and health variables and quality of life in the elderly and (b) the model's validity through correlation with depressive symptoms. The sample included 339 elderly individuals from 60 to 98 years of age $(M=73.4$; $S D=8.3)$, who answered a socio-demographic questionnaire, WHOQOL-100, and BDI. Cluster analysis of the sample distributed the elders into two groups according to self-perceived quality of life (better versus worse), and logistic regression analysis identified variables that explained better quality of life. Social class, self-rated health status, volunteer work, use of medication, and data collection setting were associated with quality of life (predictive capacity for correct classification $72.3 \%$, specificity $73.6 \%$, and sensitivity $71.1 \%)$. The inverse correlation between the model's variables and BDI scores provided evidence of the model's validity. The model can help support public policies aimed at promoting quality of life in the elderly.
\end{abstract}

Quality of Life; Health of the Elderly; Aged

\section{Resumo}

Os objetivos do estudo foram: (a) investigar relações múltiplas entre variáveis sociodemográficas, psicossociais e de saúde sobre a qualidade de vida em idosos; $e$ (b) investigar a validade do modelo pela correlação com sintomatologia depressiva. Participaram 339 idosos com idades entre 60 e 98 anos $(M=73,4 ; D P=8,3)$, os quais responderam a um questionário sociodemográfico, ao WHOQOL-100 e ao BDI. Pela análise de conglomerados os idosos foram distribuídos em dois grupos, conforme a percepção de qualidade de vida (melhor e pior) e, por meio de uma análise de regressão logística, verificou-se as variáveis que explicaram a melhor percepção de qualidade de vida. As variáveis classe social, percepção do estado de saúde, trabalho voluntário, uso de medicação e contexto de coleta se associaram à qualidade de vida (a capacidade preditiva de classificação correta foi de 72,3\%, especificidade de 73,6\% e sensibilidade de 71,1\%). A correlação inversa das variáveis do modelo com os escores do BDI indicou evidências de validade do modelo. O modelo aqui encontrado pode fomentar políticas públicas que visem à promoção da qualidade de vida de idosos.

Qualidade de Vida; Saúde do Idoso; Idoso 


\section{Introduction}

Quality of life has been defined by the WHOQOL Group (World Health Organization Quality of Life Group) as “individuals' perception of their position in life in the context of the culture and value systems where they live and in relation to their goals, expectations, standards, and concerns" 1 (p. 1405). The current study adopted this definition, among other extant ones ${ }^{2}$, to assess quality of life in a sample of elderly individuals in Rio Grande do Sul State, Brazil.

Since quality of life is a multidimensional construct, it is potentially influenced by a wide range of variables, including socio-demographic $3,4,5,6$, psychosocial $3,5,7$, and health-related $3,6,7,8,9,10,11,12,13,14$. For the first group of variables, studies have shown that elders' mean family income and level of schooling are positively associated with quality of life 5 . As for psychosocial variables, perception of family support 5 , relations with family and friends, social life and leisuretime activities 3 , and positive affects 7 have also been positively related to quality of life. Finally, health variables such as depressive symptoms $8,9,10,11,12,13$ and poor self-rated health status $3,7,15$ have shown a negative association with quality of life.

Achieving a better understanding of factors involved in quality of life in the elderly is a growing concern in the Brazilian and international literature $1,16,17,18$. In relation to the elderly population in southern Brazil, previous studies have shown an association with socio-demographic 7,19, psychosocial 7,9,14,20, and health-related variables $7,9,14$. Thus, financial conditions 7,19 and schooling 19; family relations and friendship, functional capacity and psychosocial support 14 , positive affects, independence 7 , involvement in domestic activities ${ }^{9}$, volunteer work 20 ; self-rated health status 7,14 , and health problems ${ }^{9}$ were associated with quality of life in this elderly population.

There is some degree of homogeneity of results between international and Brazilian studies, and specifically with those of southern Brazil. However, the number of studies in this region of Brazil is still insufficient to establish a solid body of knowledge on quality of life in old age. This highlights the relevance of better understanding quality of life in samples in this age group. An exploratory study was thus conducted on the multiple relations between socio-demographic, psychosocial, and health-related variables and self-perceived quality of life in elderly residents of an urban area in Rio Grande do Sul State. The study thus aimed to develop a model of variables associated with better self-perceived quality of life in old age. The study also aimed to investigate evidence of the model's validity, verifying the association between the explanatory variables for better self-perceived quality of life and depressive symptoms.

\section{Method \\ Participants}

The study sample included 339 elderly individuals ranging from 60 to 98 years of age (mean = 73.4; $\mathrm{SD}=8.3$ ), contacted either at their own homes, homes for the elderly (long-term institutions), hospitals, and community groups of elderly in Rio Grande do Sul State. The sample was comprised using an internationally standardized method, requiring a minimum of 300 participants, stratified by age, gender, and self-rated health 1,21 . This was a convenience sample 22 , and elders with terminal illnesses and dementia were excluded. Table 1 describes the sample.

As shown in Table 1, the sampling criteria were partially met, that is, $56 \%$ of the participants were females and $57 \%$ considered themselves healthy. As for stratification of the age variable, $36 \%$ of the elderly were 60 to 69 years of age, $37.2 \% 70$ to 79 years, and $26.8 \% 80$ years or older. A large proportion of the elders had low schooling $(31 \%$ were illiterate or had incomplete primary schooling) and belonged to lower social strata (48\% were socioeconomic class C). Most subjects were not currently in the work force (73.5\%), did not participate in volunteer activities (79.6\%), and were contacted in their own homes for the data collection $(67.6 \%)$. Half of the participants had a spouse or partner $(50.1 \%)$, and more than half had never smoked (55.8\%). The majority had never consumed alcoholic beverages $(60.2 \%)$, used continuous medication (83.2\%), and lived with their families $(57.4 \%)$.

\section{Instruments}

A data collection form was prepared specifically for self-reported socio-demographic, psychosocial, and health-related variables. The items in cluded gender, conjugal status, schooling, occupation, alcohol consumption, smoking, medication, self-rated health, living arrangement, volunteer work, and data collection setting (Table 1).

Self-perceived quality of life: to study quality of life in the elderly, researchers have used a generic instrument called WHOQOL-100 23, given its cross-cultural relevance. The instrument measures individual perception of quality of life and covers different areas 24 . The instrument is self-reported, answering on a scale of one to five 
Table 1

Characteristics of the sample.

\begin{tabular}{|c|c|c|}
\hline Variables & $f$ & $\%$ \\
\hline \multicolumn{3}{|l|}{ Gender } \\
\hline Male & 149 & 44.0 \\
\hline Female & 190 & 56.0 \\
\hline \multicolumn{3}{|l|}{ Conjugal status } \\
\hline Without a spouse/partner & 170 & 50.1 \\
\hline With a spouse/partner & 169 & 49.9 \\
\hline \multicolumn{3}{|l|}{ Schooling } \\
\hline Illiteratre/Incomplete Primary & 105 & 31.0 \\
\hline Complete Primary/Incomplete Junior High & 87 & 25.7 \\
\hline Complete Junior High /Incomplete Secondary & 54 & 15.9 \\
\hline Complete Secondary/Incomplete Undergraduate & 51 & 15.0 \\
\hline Complete Undergraduate University/Graduate School & 40 & 11.8 \\
\hline Other & 2 & 0.6 \\
\hline \multicolumn{3}{|l|}{ Occupation } \\
\hline Not in the labor force & 249 & 73.5 \\
\hline In the labor force & 90 & 26.5 \\
\hline \multicolumn{3}{|l|}{ Volunteer work } \\
\hline No & 270 & 79.6 \\
\hline Yes & 69 & 20.4 \\
\hline \multicolumn{3}{|l|}{ Social class } \\
\hline$E$ & 0 & 0.0 \\
\hline$D$ & 24 & 7.1 \\
\hline C & 164 & 48.4 \\
\hline B & 119 & 35.1 \\
\hline A & 32 & 9.4 \\
\hline \multicolumn{3}{|l|}{ Alcohol consumption } \\
\hline Daily & 20 & 5.9 \\
\hline Several times a week & 13 & 3.8 \\
\hline Once a week & 38 & 11.2 \\
\hline Twice a week & 13 & 3.8 \\
\hline Monthly or less & 51 & 15.0 \\
\hline Never & 204 & 60.2 \\
\hline \multicolumn{3}{|l|}{ Smoking } \\
\hline Current smoker & 27 & 8.0 \\
\hline Former smoker & 123 & 36.3 \\
\hline Never smoked & 189 & 55.8 \\
\hline \multicolumn{3}{|l|}{ Use of medication } \\
\hline Yes & 282 & 83.2 \\
\hline No & 57 & 16.8 \\
\hline \multicolumn{3}{|l|}{ Self-rated health status } \\
\hline Not healthy & 144 & 42.5 \\
\hline Healthy & 195 & 57.5 \\
\hline \multicolumn{3}{|l|}{ Housing } \\
\hline Institution & 20 & 5.9 \\
\hline Family & 251 & 57.4 \\
\hline Alone & 68 & 20.1 \\
\hline \multicolumn{3}{|l|}{ Data collection setting } \\
\hline Long-term institution & 90 & 26.5 \\
\hline Outpatient clinic & 20 & 5.9 \\
\hline Community & 229 & 67.6 \\
\hline
\end{tabular}


on 100 items distributed in six domains and 25 facets [Domain I - Physical (Facets: 1. Pain and discomfort, 2. Energy and fatigue, 3. Sleep and rest), Domain II - Psychological (Facets: 4. Positive feelings, 5. Thinking, learning, memory, and concentration, 6. Self-esteem, 7. Body image and appearance, 8. Negative feelings), Domain III Level of Independence (Facets: 9. Mobility, 10. Activities of daily life, 11. Dependency on medication or treatments, 12. Work capacity), Domain IV - Social relations (Facets: 13. Personal relations, 14. Social support, 15. Sexual activity), Domain V - Environment (Facets: 16. Physical safety and protection, 17. Home environment, 18. Financial resources, 19. Health and social care: availability and quality, 20. Opportunities to acquire new information and skills, 21. Participation in and opportunities for recreation/leisure, 22. Physical environment: pollution/noise/traffic/ weather, 23. Transportation), Domain VI - Spiritual aspects/religion/personal beliefs (Facets: 24 . Spirituality/religion/personal beliefs)]. The Facets: 25. (Overall quality of life) is a measure with four items on global aspects of the construct. The study used the Brazilian version of the instrument 25 , the psychometric properties of which have been tested and proven adequate. Analysis of the internal consistency showed Cronbach alpha coefficient ranging from 0.82 to 0.93 , and no test-retest differences were observed in the means 25. A focus group study showed that the domains and facets of the WHOQOL-100 generally proved relevant to the elderly population 26 .

Depressive symptoms: the Beck Depression Inventory (BDI) 27 was used to test the validity of the model resulting from this study. The BDI is a self-reporting instrument with 21 items scored from 0 to 3 points. Its psychometric parameters have proven adequate. Studies on the internal consistency of the Brazilian version showed Cronbach alpha coefficients from 0.70 to 0.92 . Studies on the test-retest trustworthiness showed correlation coefficients from 0.40 to 0.9127 .

\section{Design and procedures}

This was a cross-sectional, exploratory study 22 . The research project was approved by the Ethical Committee of the University Hospital in Porto Alegre (study protocol no. 01.374). Following approval, contacts were made with hospitals, institutions for the elderly, and community-dwelling elders. Recruitment also used the "snowball" technique, in which each elder recommended another. Data collection took place in 2002 and 2003, wherever it was most convenient for the subjects (hospital, health center, groups for the elderly, long-term institutions, or their own homes). After signing the informed consent form, the elders completed the form with socio-demographic, psychosocial, and self-rated health data, followed by the WHOQOL-100 and BDI.

The instruments were completed in approximately one hour, and without the presence of an accompanying person. All the instruments were self-administered, completed by the participants themselves. However, a research assistant (a medical or psychology student) was always available to clear up doubts. The study complied with all applicable ethical provisions.

\section{Data analysis}

Cluster analysis using the k-means method supported the formation of two groups due to the better distance between the six dimensions and the score for Facet 25 (overall quality of life) in WHOQOL-100. For this analysis, the scores from the six dimensions and overall quality of life were transformed into Z-scores to standardize the measure 28. Hypothetically, the two groups would be differentiated by the level of self-perceived quality of life (one group with better self-perceived quality of life and the other group with worse perception of the same construct). A descriptive and comparative analysis of the groups in the six domains and in overall quality of life in WHOQOL-100 was conducted to characterize the groups. The Student t test and effect sizes were thus calculated by Cohen's d, following the Cohen classification 29: $\mathrm{d}=0.20$ - small; $\mathrm{d}=0.50$ - medium; $\mathrm{d}=0.80$ large. Characterization of the groups also used chi-square test $\left(\chi^{2}\right)$ to compare the frequency of the study's categorical variables. The variables presenting divergent frequencies in the chisquare were identified with adjusted residuals analysis $(\geq|2|)^{30,31}$. A binary logistic regression analysis was performed by the forward conditional (stepwise) method to identify variables that explained better perceived quality of life in the sample of elderly in this study. In this analysis, the dependent variable consisted of clusters formed by cluster analysis. Validation of the model produced in this study used a correlation analysis of the variables obtained in the logistic regression for the total $\mathrm{BDI}$ score.

\section{Results}

Cluster analysis (k-means) resulted in the formation of two groups of elderly in relation to quality of life. Table 2 shows the results of this analytical procedure. The distance between the centers of the final groups was 3.013. Cluster 1 included a 
Cluster analysis ( $k$-means/two groups) for quality of life in the elderly $(n=339)$.

\begin{tabular}{lcccc}
\hline & Centers of the & final clusters & \multicolumn{2}{c}{ ANOVA } \\
& $\mathbf{1}$ & $\mathbf{2}$ & F & p-value \\
\hline Domain I - Physical Domain & 0.46915 & -0.53111 & 112.278 & $<0.001$ \\
Domain II - Psychological Domain & 0.63890 & -0.72328 & 291.109 & $<0.001$ \\
Domain III - Level of Independence & 0.55055 & -0.62327 & 176.842 & $<0.001$ \\
Domain IV - Social Relations & 0.46774 & -0.52951 & 111.381 & $<0.001$ \\
Domain V - Environment & 0.51934 & -0.58793 & 148.756 & $<0.001$ \\
Domain VI - Spirituality/Religion/Personal Beliefs & 0.40866 & -0.46264 & 78.855 & $<0.001$ \\
Overall quality of life & 0.64040 & -0.72498 & 293.677 & $<0.001$ \\
\hline
\end{tabular}

Note: cluster 1 included a total of 180 individuals, while cluster 2 consisted of 159 individuals.

total of 180 elders (53.1\% of the sample), while cluster 2 included 159 (46.9\% of the sample).

As shown in Table 2, the distances between the clusters in all dimensions of WHOQOL-100 were significant, indicating that the groups differed from each other in all measures of quality of life. Characterization of the clusters used descriptive and comparative analyses of the sociodemographic, psychosocial, health-related, and perceived quality of life variables between the groups obtained in the cluster analysis. Table 3 shows the results of these analyses.

As shown in Table 3, elders classified in cluster 1 presented higher scores than those in cluster 2 in all measures of perceived quality of life. Thus, cluster 1 consisted of elders with better self-perceived quality of life, while cluster 2 included individuals with worse perceived quality of life. The groups were equivalent in age. Cluster 1 included elders with more schooling, belonging predominantly to social class B, more involved in work and volunteer activities, using less medication, and consuming alcohol approximately once a week. The majority of this group had never smoked, considered themselves healthier, and were living in the community when the data were collected. Although the percentage was low (10\%), cluster 1 showed a higher percentage of elderly living in long-term institutions as compared to cluster 2 . Cluster 2 included elderly with lower schooling, predominantly from social class $\mathrm{C}$, living with their families, and with little involvement in work or volunteer activities. Most were on continuoususe medication, never drank alcoholic beverages, and did not rate themselves as healthy. This cluster presented higher proportions of elderly that smoked and that were hospitalized at the time of the data collection, even if the percentages were low to moderate ( $11.3 \%$ and $39 \%$, respectively).

Binary logistic regression was used to verify the socio-demographic, psychosocial, and health-related variables that explained better perceived quality of life in this sample. The dependent variable consisted of the groups formed by the cluster analysis (where the outcome was better self-perceived quality of life: cluster $1=1$, cluster $2=0$ ). The independent variables introduced in the analysis were: gender, age, conjugal status, schooling, housing, occupation, volunteer work, self-rated health status, use of medication, smoking, alcohol consumption, data collection setting, and social class (as shown in Table 1).

Table 4 shows the results of binary regression. The Omnibus test on the model's coefficients indicated that the five variables included in the last step showed a significant improvement in the model's fit [Step: $\chi^{2}(1)=7.379, \mathrm{p}=0.007$; Block and Model: $\left.\chi^{2}(5)=108.469, \mathrm{p}<0.001\right]$. The model with these five variables showed the best parameters $(-2$ log likelihood = 360.183; Cox \& Snell $\mathrm{R}^{2}=0.274$; Nagelkerk $\mathrm{R}^{2}=0.366$ ) when compared to the models of the previous steps (differences in the coefficients compared to the penultimate model: $\Delta$-2 log likelihood=-7.379; Cox \& Snell $\Delta \mathrm{R}^{2}=0.016$; Nagelkerk $\left.\Delta \mathrm{R}^{2}=0.022\right)$. The Hosmer and Lemeshow test also showed an adequate fit $\left[\chi^{2}(8)=7.530, p=0.481\right]$. The proposed model indicated that approximately $23 \%$ of the variance in better self-perceived quality of life can be explained by variation in the model's independent variables $\left(\mathrm{R}^{2}\right.$ Logit $\left.=0.231\right)$.

As shown in Table 4, the variables showing the strongest associations were self-rated health status and medication. Thus, elders who rated themselves as healthy and did not depend on medication to maintain their body functions experienced better perceived quality of life. The variables volunteer work, social class, and setting in which the data were collected were also associated. Elders involved in volunteer activities, belonging to higher social classes, and that answered the survey outside the institutional 
Table 3

Descriptive statistics and Student $t$ and $\chi^{2}$ tests comparing socio-demographic, psychosocial, and health-related variables and self-perceived quality of life between the clusters.

\begin{tabular}{|c|c|c|c|c|c|c|c|}
\hline & \multicolumn{4}{|c|}{ Clusters } & \multicolumn{3}{|c|}{ Differences } \\
\hline & \multicolumn{2}{|c|}{$1(n=180)$} & \multicolumn{2}{|c|}{$2(n=159)$} & \multirow[b]{2}{*}{$\mathbf{t}$} & \multirow[b]{2}{*}{ Degrees of freedom } & \multirow[b]{2}{*}{ p-value } \\
\hline & M & SD & M & SD & & & \\
\hline Age & 72.9 & 7.9 & 73.9 & 8.7 & 1.130 & 337 & 0.259 \\
\hline \multicolumn{8}{|l|}{ Quality of life } \\
\hline Physical & 12.9 & 1.2 & 11.5 & 1.2 & 10.596 & 337 & $<0.001$ * \\
\hline Psychological & 15.2 & 1.2 & 12.4 & 1.7 & 16.2727 & 282.938 & $<0.001 * \star$ \\
\hline Level of independence & 13.7 & 1.7 & 11.3 & 1.7 & 13.298 & 337 & $<0.001 * * \star$ \\
\hline Social relations & 14.4 & 1.5 & 12.6 & 1.6 & 10.554 & 337 & $<0.001 \#$ \\
\hline Environment & 14.6 & 1.2 & 12.9 & 1.4 & 12.197 & 337 & $<0.001$ \#\# \\
\hline Spirituality/Religion/Personal beliefs & 17.2 & 2.2 & 14.8 & 2.8 & 8.745 & 296.946 & $<0.001 \# \# \#$ \\
\hline \multirow[t]{2}{*}{ Overall quality of life } & 16.9 & 1.8 & 12.9 & 2.4 & 16.844 & 291.114 & $<0.001 \S$ \\
\hline & $f$ & $\%$ & $f$ & $\%$ & $\chi^{2}$ & Degrees of freedom & p-value \\
\hline \multicolumn{8}{|l|}{ Gender } \\
\hline Male & 71 & 39.4 & 78 & 49.1 & 3.166 & 1 & 0.075 \\
\hline Female & 109 & 60.6 & 81 & 50.9 & & & \\
\hline \multicolumn{8}{|l|}{ Schooling } \\
\hline Illiteratre/Incomplete Primary & 44 & $24.4 \S \S$ & 61 & $38.4 \S \S$ & 18.148 & 5 & 0.003 \\
\hline Complete Primary/Incomplete Junior High & 39 & 21.7 & 48 & 30.2 & & & \\
\hline Complete Junior High /Incomplete Secondary & 34 & 18.9 & 20 & 12.6 & & & \\
\hline Complete Secondary/Incomplete Undergraduate & 34 & $18.9 \S \S$ & 17 & $10.7 \S \S$ & & & \\
\hline Complete Undergraduate University/Graduate School & 28 & $15.6 \S \S$ & 12 & $7.5 \S \S$ & & & \\
\hline Other & 1 & 0.6 & 1 & 0.6 & & & \\
\hline \multicolumn{8}{|l|}{ Social class } \\
\hline A & 22 & 12.2 & 10 & 6.3 & 33.450 & 3 & $<0.001$ \\
\hline B & 82 & $45.6 \S \S$ & 37 & $23.3 \S \S$ & & & \\
\hline C & 72 & 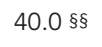 & 92 & $57.9^{*}$ & & & \\
\hline D & 4 & $1.2 \S \S$ & 20 & 12.6 & & & \\
\hline \multicolumn{8}{|l|}{ Housing } \\
\hline Institution & 18 & $10.0 \S \S$ & 2 & $1.3 \S \S$ & 17.002 & 2 & $<0.001$ \\
\hline Family & 119 & $66.1 \S \S$ & 132 & $83.0 \S \S$ & & & \\
\hline Alone & 43 & 23.9 & 25 & 15.7 & & & \\
\hline \multicolumn{8}{|l|}{ Conjugal status } \\
\hline Without spouse/partner & 93 & 51.7 & 77 & 48.4 & 0.354 & 1 & 0.552 \\
\hline With spouse/partner & 87 & 48.3 & 82 & 51.6 & & & \\
\hline \multicolumn{8}{|l|}{ Occupation } \\
\hline Not in the labor force & 120 & $66.7 \S \S$ & 129 & $81.1 \S \S$ & 9.059 & 1 & 0.003 \\
\hline In the labor force & 60 & $33.3 \S \S$ & 30 & $18.9 \S \S$ & & & \\
\hline \multicolumn{8}{|l|}{ Volunteer work } \\
\hline No & 128 & $71.1 \S \S$ & 142 & $89.3 \S \S$ & 17.245 & 1 & $<0.001$ \\
\hline Yes & 52 & $28.9 \S \S$ & 17 & $10.7 \S \S$ & & & \\
\hline \multicolumn{8}{|l|}{ Use of medication } \\
\hline Yes & 134 & $74.4 \S \S$ & 148 & $93.1 \S \S$ & 20.966 & 1 & $<0.001$ \\
\hline No & 46 & $25.6 \S \S$ & 11 & $6.9 \S \S$ & & & \\
\hline
\end{tabular}

(continues) 
Table 3 (continued)

f $\% \quad f \quad \% \quad \chi^{2} \quad$ Degrees of freedom $p$-value

\begin{tabular}{|c|c|c|c|c|c|c|c|}
\hline \multicolumn{8}{|l|}{ Alcohol consumption } \\
\hline Daily & 11 & 6.1 & 9 & 5.7 & 21.318 & 5 & 0.001 \\
\hline Several times a week & 9 & 5.0 & 4 & 2.5 & & & \\
\hline Once a week & 31 & $17.2 \S \S$ & 7 & $4.4 \S \S$ & & & \\
\hline Twice a week & 9 & 5.0 & 4 & 2.5 & & & \\
\hline Monthly or less & 29 & 16.1 & 22 & 13.8 & & & \\
\hline Never & 91 & $50.6 \S \S$ & 113 & $71.1 \S \S$ & & & \\
\hline \multicolumn{8}{|l|}{ Smoking } \\
\hline Current smoker & 9 & $5.0 \S \S$ & 18 & $11.3 \S \S$ & 6.818 & 2 & 0.033 \\
\hline Former smoker & 61 & 33.9 & 62 & 39.0 & & & \\
\hline Never smoked & 110 & $61.1 \S \S$ & 79 & $49.7 \S \S$ & & & \\
\hline \multicolumn{8}{|l|}{ Self-rated health status } \\
\hline Not healthy & 42 & $23.3 \S \S$ & 102 & $64.2 \S \S$ & 57.566 & 1 & $<0.001$ \\
\hline Healthy & 138 & $76.7 \S \S$ & 57 & $35.8 \S \S$ & & & \\
\hline \multicolumn{8}{|l|}{ Data collection setting } \\
\hline Long-term institution & 28 & $15.6 \S \S$ & 62 & $39.0 \S \S$ & 35.128 & 2 & $<0.001$ \\
\hline Outpatient clinic & 5 & $2.8 \S \S$ & 15 & $9.4 \S \S$ & & & \\
\hline Community & 147 & $81.7 \S \S$ & 82 & $51.6 \S \S$ & & & \\
\hline
\end{tabular}

* The effect size of the difference was $d=1.17$ (95\%Cl: 0.99-1.36);

** $d=1.93$ (95\%Cl: $1.75-2.19)$;

*** $d=1.42(95 \% \mathrm{Cl}: 1.17-1.68)$;

$\# \mathrm{~d}=1.17$ (95\% Cl: 0.95-1.42);

\#\# $\mathrm{d}=1.31$ (95\% Cl: 1.14-1.53);

\#\#\# $\mathrm{d}=0.96$ (95\%Cl: 0.64-1.40);

$\S d=1.91$ (95\% Cl: 1.64-2.28);

$\S$ Variables that showed significant differences.

M: mean; p: associated statistical probability; SD: standard deviation; t: Student t test; $\chi^{2}$ : chi-square test.

Table 4

Socio-demographic, psychosocial, and health-related variables resulting from logistic regression that explain better self-perceived quality of life in elderly.

\begin{tabular}{|c|c|c|c|c|c|c|c|c|}
\hline \multirow[t]{2}{*}{ Variables } & \multirow[t]{2}{*}{ B } & \multirow[t]{2}{*}{ Error } & \multirow[t]{2}{*}{ Wald } & \multirow{2}{*}{$\begin{array}{l}\text { Degree of } \\
\text { freedom }\end{array}$} & \multirow[t]{2}{*}{$p$} & \multirow[t]{2}{*}{$\operatorname{Exp}(B)$} & \multicolumn{2}{|c|}{$95 \% \mathrm{Cl} \operatorname{Exp}(\mathrm{B})$} \\
\hline & & & & & & & $\downarrow$ & $\uparrow$ \\
\hline Social class & 0.609 & 0.186 & 10.710 & 1 & 0.001 & 1.839 & 1.227 & 2.648 \\
\hline Self-rated health status & 1.336 & 0.263 & 25.859 & 1 & 0.000 & 3.802 & 2.272 & 6.363 \\
\hline Volunteer work & 0.925 & 0.349 & 7.013 & 1 & 0.008 & 2.522 & 1.272 & 5.003 \\
\hline Use of medication & 1.214 & 0.406 & 8.956 & 1 & 0.003 & 3.367 & 1.520 & 7.458 \\
\hline Data collection setting & 0.509 & 0.149 & 11.743 & 1 & 0.001 & 1.664 & 1.244 & 2.227 \\
\hline
\end{tabular}

Note: The dependent variable in the logistic regression was self-perceived quality of life, where $0=$ worse perceived quality of life $(n=159)$ and $1=$ better perceived quality of life $(n=180)$. The arrows indicate the upper and lower limits of the $95 \%$ confidence interval for the adjusted odds ratio [Exp(b)]. 
setting reported better perceived quality of life. The model with these five variables showed a specificity of $73.6 \%$ and sensitivity of $71.1 \%$ (overall correct classification was $72.3 \%$ ).

To investigate evidence for the model's validity, the correlation was analyzed between the explanatory variables and BDI 27 . Given that the literature 8,9,10,11,12,13 indicates a strong inverse association between quality of life and depression, we expected to find a negative relationship between the variables that explained better perceived quality of life and depressive symptoms in the elderly. The results confirmed the model, since an inverse relation was seen between the variables associated with better perceived quality of life and BDI (social class: $\mathrm{r}=-0.21, \mathrm{p}<0.001$; self-rated health status: $r=-0.34, p<0.001$; volunteer work: $\mathrm{r}=-0.14, \mathrm{p}=0.009$; medication: $\mathrm{r}=$ $-0.19, \mathrm{p}<0.001$; data collection setting: $\mathrm{r}=-0.21$, $\mathrm{p}<0.001$ ).

\section{Discussion}

The focus of this study was multiple relations between socio-demographic, health-related, and psychosocial variables and self-perceived quality of life in elderly residents in an urban area of Rio Grande do Sul State. Participants were divided according to their perceived quality of life (better versus worse). The socio-demographic variables examined in this study were introduced in a binary logistic regression that resulted in a model with five variables associated with self-perceived quality of life, namely social class, self-rated health status, volunteer work, medication, and data collection setting.

The resulting model was validated by association between the explanatory variables for quality of life in old age and a measure of depression. The inverse association found in the analysis indicated the resulting model's adequacy. The model thus pointed to important variables for the perception of quality of life in the elderly and that can be considered in the formulation of evaluation and intervention strategies in this age group.

Previous studies on self-perceived quality of life in the elderly have shown a relationship to self-rated health 7,24,26. This study found the same relationship. The variable self-rated health status showed explanatory power for better perceived quality of life, i.e., the elderly that saw themselves as healthier tended to perceive better quality of life. Other variables indicated by the model corroborated this result. Use of medication and data collection setting showed that elders not on medication and that were not institutionalized tended to see themselves as enjoying better quality of life.

As for elders living in long-term institutions, a study in the northern region of the State of Rio Grande do Sul with 31 elders (mean age 79.5 years) indicated a high prevalence of health problems and use of some medication. According to a questionnaire with open and closed questions, $83.9 \%$ of the elderly reported some illness (e.g., cardiovascular diseases, psychiatric disorders) and the use of some medication 32 , and these variables interfere in their perceived quality of life 33,34 . In addition, a study 35 with 66 elders (mean age 78.3 years) indicated a negative correlation $(\mathrm{r}=-0.61)$ between functional capacity and the Nottingham health profile score, i.e., a decrease in functional capacity was associated with a decrease in quality of life. Although the study was performed with a different instrument to evaluate quality of life, the result is consistent with the current study's findings, since the variables good health, daily activities, and medication vary jointly with positive perception of quality life. Importantly, however, the use of medication can be viewed by these individuals both as a factor for worse quality of life due to the decrease in autonomy, and also as an improvement due to the beneficial effect provided by certain medicines 26 . Measures to prevent diseases typically affecting the elderly, such as cardiovascular and bone conditions 32 , in addition to the direct impact on health conditions, could result in better perceived quality of life.

Volunteer work was also associated with better perceived quality of life in this sample, corroborating other studies $23,36,37$. Volunteer work has been identified as a mechanism for promotion of quality of life in the elderly and should be encouraged by health professionals 37 . An association between volunteer work and psychological and social well-being and life satisfaction in the elderly corroborated this variable's importance in experiencing what is perceived as healthy aging 23,36. One can suppose that volunteer activity assists these individuals in a more tranquil experience of the psychosocial changes resulting from aging, such as losses and changes in roles. In this sense, volunteer work plays a role in mitigating negative feelings resulting from retirement or loneliness, thereby contributing to better perceived quality of life 20 . One can also relate the finding of the Theory of Activity 38, which postulates that well-being in old age is related to the activities and roles played by the elderly in the community in which they live. Thus, individuals that fail to "replace" their social roles tend to suffer more from the aging process 38 . As indicated by other authors 36,37 , volunteer work 
can be associated with the Theory of Activity, contributing to improved quality of life in the elderly by performing different actions in social involvement and maintenance of autonomy and allowing them to preserve feelings of being active and useful. Volunteer work by the elderly is generally related to charitable activities 39,40 , also suggesting an association between altruism and quality of life. Leisure-time activities and community groups may also be associated with volunteer work, thus contributing to health promotion and quality of life, allowing elders to feel healthier and happier 41 . Other authors 24,42 have also highlighted the importance of leisure-time activities for quality of life in elderly individuals.

Social class was also associated with quality of life in the elderly. In keeping with previous studies $43,44,45$, the current study found that elders belonging to higher social classes tend to have better perceived quality of life. In old age, income tends to decrease when salaries are replaced with retirement pensions, a transition that impacts the capacity to purchase goods and services ${ }^{46}$. The financial status of the elderly interferes directly in their daily life and thus in their perception of quality of life: better socioeconomic status is associated with better quality of life in the elderly, as observed in a study of elders in pain 44 . However, this association is not always seen 47 . Still, given the strong and wellknown association between these variables, the authors reported that lack of association may have been due to the geopolitical characteristics of the city where the data were collected (a predominantly rural setting with low cost of living and satisfactory health services).

Some studies have shown that lower-income elderly are more susceptible to disease, disability, and dependency 49. According to Coelho Filho \& Ramos ${ }^{48}$, elders living in poorer areas of Fortaleza, Ceará State, Brazil, showed greater physical and mental morbidity. Thus, social status directly impacts living conditions and health status in the elderly. Income is one of the main concerns for the elderly according to another study in this population 49 , thus highlighting this variable's importance in experiencing old age with quality.

\section{Conclusions}

The quality of life model in elderly residents of Rio Grande do Sul State in the current study allows reflection on the development of public policies for this age group. Thus, preventive and health promotion measures for healthy aging are essential for quality of life in these individuals. This suggests the importance of evaluation and if necessary the expansion and optimization of government programs for health in the elderly. Veras 50 proposed a screening system to ensure more adequate healthcare for this group. This procedure allows the hierarchical management of health risks for the elderly, which contributes to a more effective health system with better case resolution. Such measures tend to favor access to health by the elderly. High-quality prevention and intervention programs can decrease the rates of medicalization and hospitalization in this age group, guaranteeing the right of elders to be actively involved in their communities.

Volunteer work enters this scenario as a resource to promote quality of life. As indicated by the World Health Organization 51, this type of practice can be an effective alternative for promoting active aging. This kind of measure can thus be implemented and promoted, thereby helping increase the expectation of a healthy life with quality.

Importantly, the model obtained with the variables analyzed here was capable of explaining quality of life in the elderly with $72.3 \%$ power of correct classification. Thus, it is believed that other variables not assessed here may influence perceived quality of life in the elderly, e.g., nutritional adequacy 20 , issues related to obtaining pleasure and comfort 24 , personality variables 37 , and physical activity ${ }^{52}$. In addition, this study did not control for possible psychiatric and neurological diagnoses in participants, which limits interpretation of the findings. The study's limitations thus include the limited range of variables investigated for analysis of association with better self-perceived quality of life; the use of a convenience sample, resulting lack of control and formation of distinct groups of elderly, with different clinical conditions and lifestyles. We suggest replicating the resulting model, verifying its effectiveness in other settings and cultures, and the investigation of the model's expansion with the inclusion of other independent variables.

Nevertheless, despite the study limitations, the model allows evaluation and elaboration of preventive programs and promotion of quality of life in elderly in the State of Rio Grande do Sul. Aging need not be synonymous with declining quality of life. On the contrary, having identified the variables associated with quality of life, government and healthcare and social institutions can (and should) ensure dignity for citizens in this life phase. It is hoped that the current study will contribute to the discussion on aging in the Brazilian population and especially that it will serve as the basis for the elaboration of effective action in promoting quality of life in this age group. 


\section{Resumen}

Los objetivos del estudio fueron: (a) investigar relaciones múltiples entre variables sociodemográficas, psicosociales y de salud sobre la calidad de vida en ancianos; $e$ (b) investigar la validez del modelo por la correlación con la sintomatología depresiva. Participaron 339 ancianos con edad entre 60 y 98 años $(M=73,4 ; D P=$ 8,3), quienes respondieron a un cuestionario sociodemográfico, el WHOQOL-100 y el BDI. Por el análisis de conglomerados los ancianos fueron distribuidos en dos grupos, conforme la percepción de calidad de vida (mejor y peor) y, por medio de un análisis de regresión logística, se verificaron las variables que explicaron la mejor percepción de calidad de vida. Las variables clase social, percepción del estado de salud, trabajo voluntario, uso de medicación y contexto de recogida se asociaron a la calidad de vida (la capacidad predictiva de clasificación correcta fue de un 72,3\%, especificidad de un 73,6\% y sensibilidad de un 71,1\%). La correlación inversa de las variables del modelo con los marcadores del BDI indicó evidencias de validez del modelo. El modelo aquí encontrado puede fomentar políticas públicas que tengan por objetivo la promoción de la calidad de vida de los ancianos.

Calidad de Vida; Salud del Anciano; Anciano

\section{References}

1. The World Health Organization Quality of Life Assessment (WHOQOL): position paper from the World Health Organization. Soc Sci Med 1995; 41:1403-9.

2. Neri AL. Qualidade de vida na velhice e atendimento domiciliário. In: Duarte YAO, Diogo MDJ, organizadores. Atendimento domiciliar: um enfoque gerontológico. São Paulo: Editora Atheneu; 2000. p. 33-47.

3. Bowling A. What things are important in people's lives? A survey on the public's judgments to inform scales on health related quality of life. Soc Sci Med 1995; 41:1447-62.

4. Kirchengast S, Haslinger B. Gender differences in health-related quality of life among healthy aged and old-aged Austrians: cross-sectional analysis. Gend Med 2008; 5:270-8.

5. Inouye K, Barham EJ, Pedrazzani ES, Pavarini SCI. Percepções de suporte familiar e qualidade de vida entre idosos segundo a vulnerabilidade social. Psicol Refl Crít 2010; 23:582-92.

\section{Contributors}

S. E. S. Oliveira, J. V. Hohendorff, and J. L. Müller contributed to the design, data analysis and interpretation, and writing of the article. D. R. Bandeira, S. H. Koller and C. M. Trentini collaborated in the design, relevant critical revision of the intellectual content, and approval of the final version for publication. M. P. A. Fleck participated in the design, data analysis and interpretation, relevant critical revision of the intellectual content, and approval of the final version for publication.
6. Paschoal SMP, Jacob Filho W, Litvoc J. Development of Elderly Quality of Life Index - EqoLI: Item reduction and distribution into dimensions. Clinics 2008; 63:179-88.

7. Irigaray TQ, Trentini CM. Qualidade de vida em idosas: a importância da dimensão subjetiva. Estud Psicol (Campinas) 2009; 26:297-304.

8. Chachamovich E, Fleck MPA, Laidlaw K, Power M. Impact of major depression and subsyndromal symptoms on Quality of Life and attitudes toward aging in an international sample of older adults. Gerontologist 2008; 48:593-602.

9. Xavier FMF, Ferraz MPT, Marc N, Escosteguy N, Moriguchi EH. Elderly people's definition of quality of life. Rev Bras Psiquiatr 2003; 25:31-9.

10. Lima AFBS, Fleck, MPA. Qualidade de vida e depressão: uma revisão da literatura. Rev Psiquiatr Rio Gd Sul 2009; 31(3 Suppl). http://www.scielo. br/pdf/rprs/v31n3s0/v31n3a02s1.pdf. 
11. Nakabayashi TIK, Chagas MHN, Corrêa ACL, Tumas V, Loureiro SR, Crippa JAS. Prevalência de depressão na doença de Parkinson. Rev Psiquiatr Clin 2008; 35:219-27.

12. Paula JA, Roque FP, Araújo FS. Qualidade de vida em cuidadores de idosos portadores de demência de Alzheimer. J Bras Psiquiatr 2008; 57:283-7.

13. Pinto MX, Custódio O, Makdisse M. Incidência de depressão e fatores associados em idosos residentes na comunidade: revisão de literatura. Rev Bras Geriatr Gerontol 2009; 12:123-40.

14. Moraes JFD, Souza VBA. Factors associated with the successful aging of the socially active elderly in the metropolitan region of Porto Alegre. Rev Bras Psiquiatr 2005; 27:302-8.

15. Browne JP, O'Boyle CA, McGee HM, Joyce CRB, McDonald NJ, O'Malley K, et al. Individual quality of life in the healthy elderly. Qual Life Res 1994; 3:235-44.

16. Vecchia RD, Ruiz T, Bocchi SCM, Corrente JE. Qualidade de vida na terceira idade: Um conceito subjetivo. Rev Bras Epidemiol 2005; 8:246-52.

17. Campbell A, Converse PE, Rodgers WL. The quality of American life: perceptions, evaluations, and satisfactions. New York: Russell Sage; 1976.

18. Lawton MP. A multidimensional view of quality of life in frail elders. In: Birren JE, Lubben J, Rowe J, Deutchman D, editors. The concept and measurement of quality of life. New York: Academic Press; 1991. p. 3-27.

19. Colet CF, Mayorga P, Amador TA. Educational level, socio-economic status and relationship with quality of life in elderly residents of the city of Porto Alegre/RS, Brazil. Braz J Pharm Sci 2010; 46:805-10.

20. Souza LM, Lautert L, Hilleshein EF. Qualidade de vida e trabalho voluntário em idosos. Rev Esc Enferm USP 2011; 45:665-71.

21. Power M, Quinn K, Schmidt S. Development of the WHOQOL-Old module. Qual Life Res 2005; 14:2197-214.

22. Cozby PC. Métodos de pesquisa em ciências do comportamento. São Paulo: Editora Atlas; 2003.

23. The World Health Organization Quality of Life Assessment (WHOQOL): development and general psychometric properties. Soc Sci Med 1998; 46:1569-85.

24. Trentini CM, Chachamovich E, Wagner GP, Müller DH, Hirakata VN, Fleck MPA. Quality of life (QoL) in a Brazilian sample of older adults: the role of sociodemographic variables and depression symptoms. Appl Res Qual Life 2011; 6:291-309.

25. Fleck MPA, Fachel O, Louzada S, Xavier M, Chachamovich E, Vieira G, et al. Desenvolvimento da versão em português do instrumento de avaliação de qualidade de vida da Organização Mundial da Saúde (WHOQOL-100). Rev Bras Psiquiatr 1999; 21:19-28.

26. Fleck MPA, Chachamovich E, Trentini CM. Projeto WHOQOL-OLD: método e resultado de grupos focais no Brasil. Rev Saúde Pública 2003; 37:793-9.

27. Cunha JA. Manual da versão em português das Escalas Beck. São Paulo: Casa do Psicólogo; 2001.

28. Hair Junior JF, Anderson RE, Tatham RL, Black WC. Análise multivariada de dados. 5a Ed. Porto Alegre: Bookman; 2005.
29. Cohen J. Statistical power analysis for the behavioral sciences. 2nd Ed. Hillsdale: Lawrence Erlbaum Associates; 1988.

30. Anscombe FJ, Tukey W. The examination and analysis of residuals. Technometrics 1963; 5:141-60.

31. Oliveira C. Análise de resíduos em tabelas de contingência [Master's Thesis]. Porto Alegre: Universidade Federal do Rio Grande do Sul; 2000.

32. Aires M, Paz AP, Perosa CT. Situação de saúde e grau de dependência de pessoas idosas institucionalizadas. Rev Gaúcha Enferm 2009; 30:492-9.

33. Figueira HA, Giani TS, Beresford H, Ferreira MA, Mello D, Figueira AA, et al. Quality of life (QOL) axiological profile of the elderly population served by the Family Health Program (FHP) in Brazil. Arch Gerontol Geriat 2009; 49:368-72.

34. Tavares EL, Anjos LA. Perfil antropométrico da população idosa brasileira. Resultados da Pesquisa Nacional sobre Saúde e Nutrição. Cad Saúde Pública 1999; 15:759-68.

35. Mincato PC, Freitas CLR. Qualidade de vida dos idosos residentes em instituições asilares da cidade de Caxias do Sul - RS. Revista Brasileira de Ciências do Envelhecimento Humano 2007; 4:127-38.

36. Shmotkin D, Blumstein T, Modan B. Beyond keeping active: concomitants of being a volunteer in old-old age. Psychol Aging 2003; 18:602-7.

37. Neri AL. Qualidade de vida no adulto maduro: interpretações teóricas e evidências de pesquisa. In: Neri AL, organizador. Qualidade de vida e idade madura. Campinas: Papirus; 2007. p. 9-86.

38. Siqueira MEC. Teorias sociológicas do envelhecimento. In: Freitas EV, Py L, Neri AL, Cançado FAX, Gorzoni ML, Rocha SM, organizadores. Tratado de geriatria e gerontologia. Rio de Janeiro: Guanabara Koogan; 2002. p. 47-57.

39. Abreu NS, Baracho ES, Tirado MGA, Dias RC. Qualidade de vida na perspectiva de idosas com incontinência urinária. Rev Bras Fisioter 2007; 11:429-36.

40. Souza LM, Lautert L. Trabalho voluntário: uma alternativa para a promoção da saúde de idosos. Rev Esc Enferm USP 2008; 42: 363-70.

41. Borini MLO, Cintra, FA. Representações sociais da participação em atividades de lazer em grupos de terceira idade. Rev Bras Enferm 2002; 55:568-74.

42. Alexandre TS, Cordeiro RC, Ramos LR. Factors associated to quality of life in active elderly. Rev Saúde Pública 2009; 43:613-21.

43. Chaimowicz F. A saúde dos idosos brasileiros às vésperas do século XXI: problemas, projeções e alternativas. Rev Saúde Pública 1997; 31:184-200.

44. Jakobsson U, Hallberg IR, Westergren A. Overall and health related quality of life among the oldest old in pain. Qual Life Res 2004; 13:125-36.

45. Sherbourne CD, Meredith LS, Rogers W, Ware JEJ. Social support and stressful life events: age differences in their effects on health related quality of life among chronically ill. Qual Life Res 1992; 1:235-46.

46. Paes de Barros R, Mendonça R, Santos D. Incidência e natureza da pobreza entre idosos no Brasil. Rio de Janeiro: Instituto de Pesquisa Econômica Aplicada; 1999. 
47. Pereira RJ, Cotta RMM, Franceschini SCC, Ribeiro RCL, Sampaio RF, Priore SE, et al. Contribuições dos domínios físico, social, psicológico e ambiental para a qualidade de vida global de idosos. Rev Psiquiatr Rio Gd Sul 2006; 28:27-38.

48. Coelho Filho JM, Ramos LR. Epidemiologia do envelhecimento no Nordeste do Brasil: resultados de inquérito domiciliar. Rev Saúde Pública 1999; 33:445-53.

49. Santos SR, Santos IBC, Fernandes MGM, Henriques MERM. Qualidade de vida do idoso na comunidade: aplicação da Escala de Flanagan. Rev Latinoam Enferm 2002; 10:757-64.

50. Veras R. Em busca de uma assistência adequada à saúde do idoso: revisão da literatura e aplicação de um instrumento de detecção precoce e de previsibilidade de agravos. Cad Saúde Pública 2003; 19:705-15.
51. Organização Mundial da Saúde. Envelhecimento ativo: uma política de saúde. Brasília: Organização Pan-Americana da Saúde; 2005.

52. Januário RSB, Serassuelo HJ, Liutti MC, Decker D, Molari M. Qualidade de vida em idosos ativos e sedentários. Conscientiae Saúde (Impr.) 2011; 10: 112-21.

Submitted on 29/Aug/2012

Final version resubmitted on 15/Dec/2012

Approved on 11/Jan/2013 
Oliveira SES, Hohendorff JV, Müller JL, Bandeira DR, Koller SH, Fleck MPA, Trentini CM. Associations between self-perceived quality of life and socio-demographic, psychosocial, and health variables in a group of elderly. Cad Saúde Pública $2013 ; 29(7): 1436-1448$.

A revista foi informada sobre um erro na Tabela 3. A tabela correta é:

The journal has been informed of an error in the Table 3. The correct table is:

La revista fue informada sobre un error en la Tabla 3. La tabla correcta es:

\begin{tabular}{|c|c|c|c|c|c|c|c|}
\hline & \multicolumn{4}{|c|}{ Clusters } & \multicolumn{3}{|c|}{ Differences } \\
\hline & \multicolumn{2}{|c|}{$1(n=180)$} & \multicolumn{2}{|c|}{$2(n=159)$} & \multirow[b]{2}{*}{$\mathbf{t}$} & \multirow[b]{2}{*}{ Degrees of freedom } & \multirow[b]{2}{*}{ p-value } \\
\hline & M & SD & M & SD & & & \\
\hline Age & 72.9 & 7.9 & 73.9 & 8.7 & 1.130 & 337 & 0.259 \\
\hline \multicolumn{8}{|l|}{ Quality of life } \\
\hline Physical & 12.9 & 1.2 & 11.5 & 1.2 & 10.596 & 337 & $<0.001$ * \\
\hline Psychological & 15.2 & 1.2 & 12.4 & 1.7 & 16.2727 & 282.938 & $<0.001 * \star$ \\
\hline Level of independence & 13.7 & 1.7 & 11.3 & 1.7 & 13.298 & 337 & $<0.001 * \star \star$ \\
\hline Social relations & 14.4 & 1.5 & 12.6 & 1.6 & 10.554 & 337 & $<0.001 \#$ \\
\hline Environment & 14.6 & 1.2 & 12.9 & 1.4 & 12.197 & 337 & $<0.001 \#$ \\
\hline Spirituality/Religion/Personal beliefs & 17.2 & 2.2 & 14.8 & 2.8 & 8.745 & 296.946 & $<0.001 \# \# \#$ \\
\hline \multirow[t]{2}{*}{ Overall quality of life } & 16.9 & 1.8 & 12.9 & 2.4 & 16.844 & 291.114 & $<0.001 \S$ \\
\hline & f & $\%$ & $f$ & $\%$ & $\chi^{2}$ & Degrees of freedom & p-value \\
\hline \multicolumn{8}{|l|}{ Gender } \\
\hline Male & 71 & 39.4 & 78 & 49.1 & 3.166 & 1 & 0.075 \\
\hline Female & 109 & 60.6 & 81 & 50.9 & & & \\
\hline \multicolumn{8}{|l|}{ Schooling } \\
\hline Illiteratre/Incomplete Primary & 44 & $24.4 \S \S$ & 61 & $38.4 \S \S$ & 18.148 & 5 & 0.003 \\
\hline Complete Primary/Incomplete Junior High & 39 & 21.7 & 48 & 30.2 & & & \\
\hline Complete Junior High /Incomplete Secondary & 34 & 18.9 & 20 & 12.6 & & & \\
\hline Complete Secondary/Incomplete Undergraduate & 34 & $18.9 \S \S$ & 17 & $10.7 \S \S$ & & & \\
\hline Complete Undergraduate University/Graduate School & 28 & $15.6 \S \S$ & 12 & $7.5 \S \S$ & & & \\
\hline Other & 1 & 0.6 & 1 & 0.6 & & & \\
\hline
\end{tabular}

(continues) 


\begin{tabular}{|c|c|c|c|c|c|c|c|}
\hline \multicolumn{8}{|l|}{ Social class } \\
\hline$A$ & 22 & 12.2 & 10 & 6.3 & 33.450 & 3 & $<0.001$ \\
\hline B & 82 & $45.6 \S \S$ & 37 & $23.3 \S \S$ & & & \\
\hline C & 72 & $40.0 \S \S$ & 92 & $57.9^{*}$ & & & \\
\hline$D$ & 4 & $1.2 \S \S$ & 20 & 12.6 & & & \\
\hline \multicolumn{8}{|l|}{ Housing } \\
\hline Institution & 18 & $10.0 \S \S$ & 2 & $1.3 \S \S$ & 17.002 & 2 & $<0.001$ \\
\hline Family & 119 & $66.1 \S \S$ & 132 & $83.0 \S \S$ & & & \\
\hline Alone & 43 & 23.9 & 25 & 15.7 & & & \\
\hline \multicolumn{8}{|l|}{ Conjugal status } \\
\hline Without spouse/partner & 93 & 51.7 & 77 & 48.4 & 0.354 & 1 & 0.552 \\
\hline With spouse/partner & 87 & 48.3 & 82 & 51.6 & & & \\
\hline \multicolumn{8}{|l|}{ Occupation } \\
\hline Not in the labor force & 120 & $66.7 \S \S$ & 129 & $81.1 \S \S$ & 9.059 & 1 & 0.003 \\
\hline In the labor force & 60 & $33.3 \S \S$ & 30 & $18.9 \S \S$ & & & \\
\hline \multicolumn{8}{|l|}{ Volunteer work } \\
\hline No & 128 & $71.1 \S \S$ & 142 & $89.3 \S \S$ & 17.245 & 1 & $<0.001$ \\
\hline Yes & 52 & $28.9 \S \S$ & 17 & $10.7 \S \S$ & & & \\
\hline \multicolumn{8}{|l|}{ Use of medication } \\
\hline Yes & 134 & $74.4 \S \S$ & 148 & $93.1 \S \S$ & 20.966 & 1 & $<0.001$ \\
\hline No & 46 & $25.6 \S \S$ & 11 & $6.9 \S \S$ & & & \\
\hline \multicolumn{8}{|l|}{ Alcohol consumption } \\
\hline Daily & 11 & 6.1 & 9 & 5.7 & 21.318 & 5 & 0.001 \\
\hline Several times a week & 9 & 5.0 & 4 & 2.5 & & & \\
\hline Once a week & 31 & $17.2 \S \S$ & 7 & $4.4 \S \S$ & & & \\
\hline Twice a week & 9 & 5.0 & 4 & 2.5 & & & \\
\hline Monthly or less & 29 & 16.1 & 22 & 13.8 & & & \\
\hline Never & 91 & $50.6 \S \S$ & 113 & $71.1 \S \S$ & & & \\
\hline \multicolumn{8}{|l|}{ Smoking } \\
\hline Current smoker & 9 & $5.0 \S \S$ & 18 & $11.3 \S \S$ & 6.818 & 2 & 0.033 \\
\hline Former smoker & 61 & 33.9 & 62 & 39.0 & & & \\
\hline Never smoked & 110 & $61.1 \S \S$ & 79 & $49.7 \S \S$ & & & \\
\hline \multicolumn{8}{|l|}{ Self-rated health status } \\
\hline Not healthy & 42 & $23.3 \S \S$ & 102 & $64.2 \S \S$ & 57.566 & 1 & $<0.001$ \\
\hline Healthy & 138 & $76.7 \S \S$ & 57 & $35.8 \S \S$ & & & \\
\hline \multicolumn{8}{|l|}{ Data collection setting } \\
\hline Long-term institution & 28 & $15.6 \S \S$ & 62 & 39.0 §§ & 35.128 & 2 & $<0.001$ \\
\hline Outpatient clinic & 5 & $2.8 \S \S$ & 15 & $9.4 \S \S$ & & & \\
\hline Community & 147 & $81.7 \S \S$ & 82 & $51.6 \S \S$ & & & \\
\hline
\end{tabular}

* The effect size of the difference was $d=1.17$ (95\% Cl: 0.99-1.36);

** $d=1.93(95 \% \mathrm{Cl}: 1.75-2.19)$;

$\star \star \star ~ d=1.42(95 \% \mathrm{Cl}: 1.17-1.68)$;

$\# \mathrm{~d}=1.17$ (95\% Cl: 0.95-1.42);

\#\# $\mathrm{d}=1.31(95 \% \mathrm{Cl}: 1.14-1.53)$;

\#\#\# $d=0.96$ (95\%Cl: 0.64-1.40);

$\S \mathrm{d}=1.91(95 \% \mathrm{Cl}: 1.64-2.28)$;

$\S \S$ Variables that showed significant differences.

M: mean; p: associated statistical probability; SD: standard deviation; t: Student t test; $\chi^{2}$ : chi-square test. 